\title{
Design and Implementation of Series Resonant DC-DC Converter
}

\author{
Firmansyah Nur Budiman* dan Arridha Amrad \\ Department of Electrical Engineering, Faculty of Industrial Technology, Universitas Islam Indonesia \\ Sleman, Daerah Istimewa Yogyakarta, Indonesia \\ *Corresponding author, e-mail: firmansyah.nur@uii.ac.id
}

\begin{abstract}
The resonant DC-DC converter is known as advantageous over conventional DC-DC converter in terms of efficiency. This is primarily because the resonant converter operates at soft switching mode. In this paper, we report our work on the design and implementation of a series resonant DC-DC converter with full-bridge switching. The developed converter consisted of two main parts, namely the PWM signal-generating circuit as the driver for MOSFET and converter primary circuit. The first part was implemented by using Arduino UNO R3, whose output was amplified with IR2110 optocoupler. The latter was made up of full-bridge inverter, which employs MOSFET as the electronic switches, resonance circuit, and full-bridge uncontrolled rectifier. Performance of the developed converter was tested by supplying input voltage ranging from 20 to $30 \mathrm{~V}$. It was shown that the converter functioned as a step-down "DC" transformer, i.e. voltage reducer. The maximum output voltage level obtained was half of the input, which was achieved at switching frequency of $40 \mathrm{kHz}$ and efficiency of $50 \%$. The converter was also tested to supply practical electrical load. In this case, a $12-\mathrm{V}$ electric drill was put in place. The drill worked well, and a converter efficiency of $43 \%$ could be calculated during this operation.
\end{abstract}

Keywords : DC-DC Converter, Series Resonance and Switching

\section{Introduction}

In power electronic converters, higher switching frequency is preferable because it can decrease the converter size [1]. However, there will be a problem when the switching is not perfect. Imperfect switching is responsible for switching losses inside the converter circuits. Higher losses result in low converter efficiency.

One way to reduce this switching losses is by employing resonant circuit, in which the switching scheme is referred to as "soft switching" [2]. In soft switching, on-off transitions occur when the values of voltage and current are zero. Soft switching was introduced to obtain high-efficiency converter and to reduce electromagnet interference (EMI) level as well [3].

Among the converters that can apply the principle of soft switching is the DC-DC converter. DC-DC converters have found many applications in power system, mainly for the purpose of interfacing renewable energy (e.g. wind turbine, solar cell) to existing power system [4], [5]. Special form of DCDC converters that employ soft switching is called resonant DC-DC converters. In resonant DC-DC converters, output voltage is controlled by varying circuit's switching frequency [6].

Being attracted to these advantages, we have developed small-scale series resonant DC-DC converter and we aim to present the result in this paper. We start by describing basic concept of resonant DC-DC converter, especially series resonant converter. Subsequently, we explain the design and implementation work involved. Afterwards, we elaborate converter's performance in details.

\section{Concept of Series Resonance DC-DC Converter}

Series resonant DC-DC converter is DC-DC converter whose output voltage is governed by its switching frequency. The term "series" represent its series connection between capacitor and inductor in its resonant circuit [7]. Signal flow in series resonant DC-DC converter is processed in three stages. In first stage, input DC voltage is converted to $\mathrm{AC}$ by means of full-bridge inverter. The second stage involves tuning the switching frequency in order to obtain resonance. In the last stage, the AC signal is converter back to DC 
through full-bridge rectifier. Configuration of series resonant DC-DC converter is shown in Fig. 1.

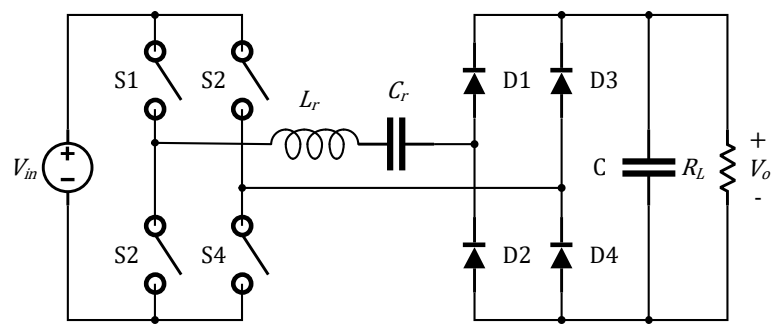

Figure 1. Circuit diagram of series resonant DCDC converter

Resonant network consists of series connection of inductor $L_{r}$ and capacitor $C_{r}$. The important parameters of the converter are defined in (1)-(4),

$$
\begin{gathered}
X_{L}=\omega_{s} L_{r} \\
X_{C}=\frac{1}{\omega_{s} C_{r}} \\
\omega_{s}=2 \pi f_{s} \\
f_{r}=\frac{1}{2 \pi \sqrt{L_{r} C_{r}}}
\end{gathered}
$$

where $X_{L}$ is inductive reactance of $L_{r}(\Omega), X_{C}$ is capacitive reactance of $C_{r}(\Omega), f_{r}$ is circuit resonant frequency $(\mathrm{Hz})$, and $f_{s}$ and $\omega_{s}$ is circuit switching frequency $(\mathrm{Hz})$ and angular switching frequency $(\mathrm{rad} / \mathrm{s})$, respectively.

The magnitude of output voltage $V_{o}$ is regulated by controlling switching frequency $\omega_{s}$. This is governed by (5),

$$
\frac{V_{o}}{V_{i n}}=\frac{1}{2}\left(\frac{1}{\sqrt{1+\left[\left(X_{L}-X_{C}\right) / R_{e q}\right]^{2}}}\right)
$$

where $V_{\text {in }}$ is circuit input voltage $(\mathrm{V})$ and $R_{e q}$ is circuit equivalent resistance. The term $V_{o} / V_{i n}$ is also known as voltage gain. $R_{e q}$ is approximated by (6),

$$
R_{e q}=\left(\frac{8}{\pi^{2}}\right) R_{L}
$$

where $R_{L}$ is the load resistance $(\Omega)$. The sensitivity of the output to the switching frequency depends of the values of $L_{r}$ and $C_{r}$.

Another important parameter of series resonant DC-DC converter is the circuit quality factor $Q$, which is defined by (7),

$$
Q=\frac{\omega_{r} L_{r}}{R_{L}}
$$

where $\omega_{r}$ is the circuit resonant frequency $(\mathrm{rad} / \mathrm{s})$. How $Q$ value affects the voltage gain is depicted in Fig. 2. As shown in Fig. 2, maximum output voltage is theoretically equal to input voltage when circuit operates at resonant frequency, $\omega_{s}=$ $\omega_{r}$.

Ideally, converter output power is equal to its input power. However, voltage drop $V_{c H}$ introduced during switching of four MOSFET in the inverter part obviously contributes to the power loss [8], which could reduce circuit efficiency. Converter efficiency $\eta$ is calculated as in (8).

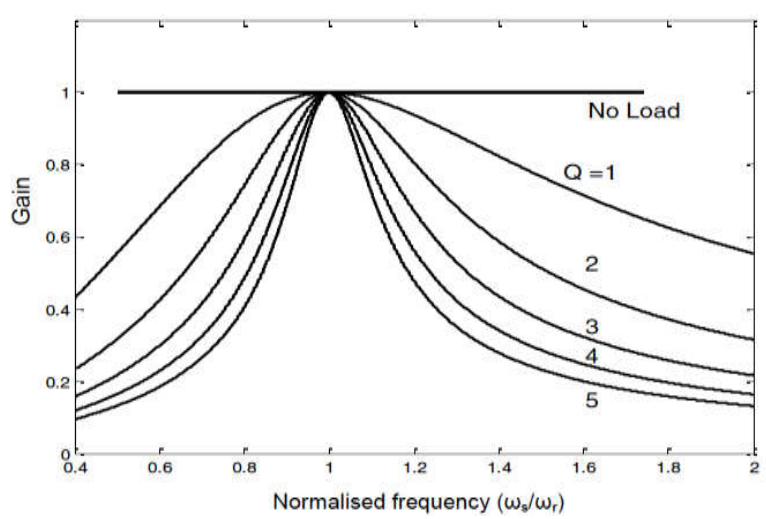

Figure 2. Normalized frequency response of series resonant DC-DC converter

$$
\eta=\frac{P_{o}}{P_{\text {in }}} \times 100 \%
$$

where input and output powers are calculated as in (9) and (10),

$$
\begin{aligned}
P_{\text {in }} & =\frac{1}{T} \int_{0}^{k T} v_{0} I_{0} d t \\
& =\frac{1}{T} \int_{0}^{k T} \frac{V_{0}^{2}}{R_{L}} d t=\frac{k V_{i n}^{2}}{R_{L}}
\end{aligned}
$$




$$
\begin{aligned}
P_{o} & =\frac{1}{T} \int_{0}^{k T} \frac{V_{0}^{2}}{R} d t \\
& =\frac{1}{T} \int_{0}^{k T} \frac{\left(V_{i n}-V_{c H}\right)^{2}}{R_{L}} d t \\
& =k \frac{\left(V_{i n}-V_{c H}\right)^{2}}{R_{L}}
\end{aligned}
$$

\section{Converter Design and Implementation}

As indicated in previous section, the developed series resonant DC-DC converter was made up two parts, namely driver circuit and main circuit. In main circuit, input voltage was converted to $\mathrm{AC}$ and then converted back to DC. Fig. 3 shows the block diagram of the developed converter, while Table 1 lists its specification. In this converter, electronic switches used in inverter circuit are MOSFET.

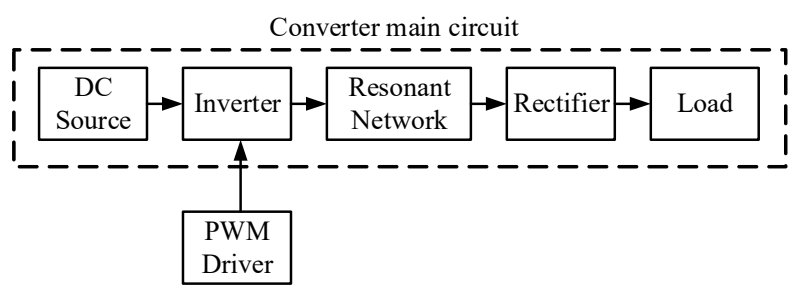

Figure 3. Functional block diagram of the developed converter

Table 1. Design parameter of the developed converter

\begin{tabular}{|l|c|}
\hline \multicolumn{1}{|c|}{ Parameter } & Value \\
\hline Input Voltage & $20 \mathrm{~V}_{\mathrm{DC}}-30 \mathrm{~V}_{\mathrm{DC}}$ \\
Input Current & $0,1 \mathrm{~A}-0,73 \mathrm{~A}$ \\
Input Power & $2 \mathrm{~W}-22 \mathrm{~W}$ \\
MOSFET Gate Voltage & $12 \mathrm{~V}_{\mathrm{DC}}$ \\
Resonant Frequency & $50 \mathrm{kHz}$ \\
Switching Frequency & $10 \mathrm{kHz}-100 \mathrm{kHz}$ \\
Duty Cycle & $50 \%$ \\
Maximum Output Current & $0,73 \mathrm{~A}$ \\
Maximum Output Voltage & $15 \mathrm{~V} \mathrm{~V}_{\mathrm{DC}}$ \\
Maximum Output Power & $11 \mathrm{~W}$ \\
\hline
\end{tabular}

Desired converter parameters, as in Table 1, are to be achieved through the following design steps.

\section{a. Design of PWM controller circuit}

PWM signals are used for controlling switching mechanism of the full-bridge inverter. In our converter, we utilize Arduino UNO R3 for this purpose. PWM signals were generated in the range of $10-100 \mathrm{kHz}$ with duty cycle of $50 \%$. These signals were of $5-\mathrm{V}$ amplitude and in our practice, this value was not high enough to drive the inverter's MOSFET into saturation area. Therefore, we amplified these signals before injecting them into the MOSFET of full-bridge inverter. A value of $12 \mathrm{~V}$ was found to be enough to fire the MOSFET. IR2110 optocoupler was employed for this task.

\section{b. Design of full-bridge inverter circuit}

In our inverter circuit, we used IRFZ44N series MOSFET for switching. Its specification is presented below,

- Drain source breakdown voltage: $55 \mathrm{~V}$

- Gate source breakdown voltage: $20 \mathrm{~V}$

- Gate threshold voltage $V_{T h}: 4 \mathrm{~V}$

- Drain source ON resistance $R_{D S(O N)}: 0.0175$

$\Omega$

Fig. 4 shows the relationship between gate-tosource voltage $V_{G S}$ and $I_{D}$ of IRFZ44N. As shown in Fig. 4, theoretically a $V_{G S}$ value of $5 \mathrm{~V}$ is enough to drive the MOSFET to ON mode. However, practically it is not in such way. We set $V_{G S}$ to maximum allowable values of $12 \mathrm{~V}$.

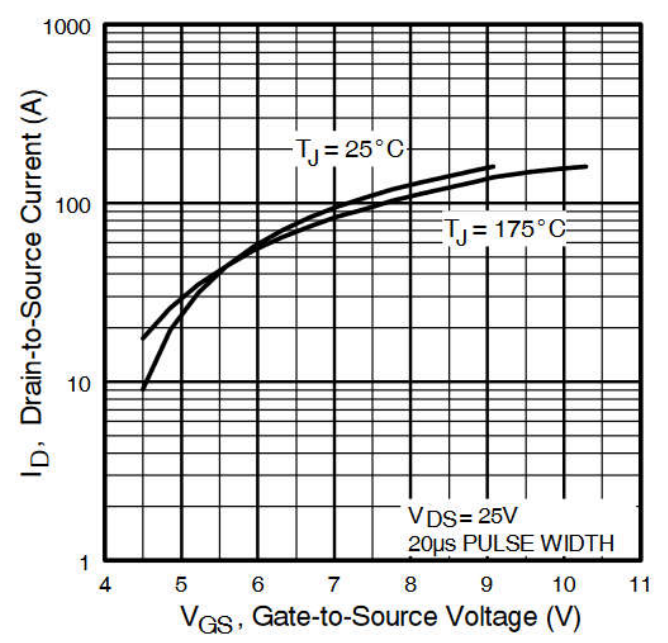

Figure 4. $I_{D}$ vs $V_{G S}$ relationship of IRFZ44N series MOSFET [9]

\section{c. Design of resonant circuit}

In resonant circuit, a $100-\mathrm{nF}$ capacitor and a $100-\mu \mathrm{H}$ were used. Therefore, by using (4), resonant frequency of the circuit was found to be $50.35 \mathrm{kHz}$, or 316223.12 in terms of $\mathrm{rad} / \mathrm{s}$. Because maximum power that can be handled by the developed converter is around $20 \mathrm{~W}$, we 
choose ceramic resistor of $20 \mathrm{~W} / 22 \mathrm{RJ}$ as converter load. According to (6), circuit equivalent resistor $R_{e q}$ was found to be $17.85 \Omega$. Also, quality factor $Q$ was also calculated using (7) and was found to be 1.771 .

\section{d. Design of full-bridge rectifier}

As uncontrolled rectifier is enough [10], we used diode for the purpose of rectification. Ultrafast diode of UF4007 series was put in place. This type of diode has a voltage limit of $1000 \mathrm{~V}$ and a current limit of $1 \mathrm{~A}$. To reduce the ripple of the rectifier output, a capacitor of $1000 \mu \mathrm{F}$ was employed as filter. This capacitor was placed in parallel with the load.

\section{Results and Discussions}

The developed series resonant DC-DC converter is shown in Fig. 5. The first conducted experiment was varying switching frequency at fixed input voltage. We took two input voltage values for comparison. The switching frequency was then plotted against output voltage $V_{o}$ and output current $I_{o}$. The results are shown in Fig. 6 and Fig. 7.

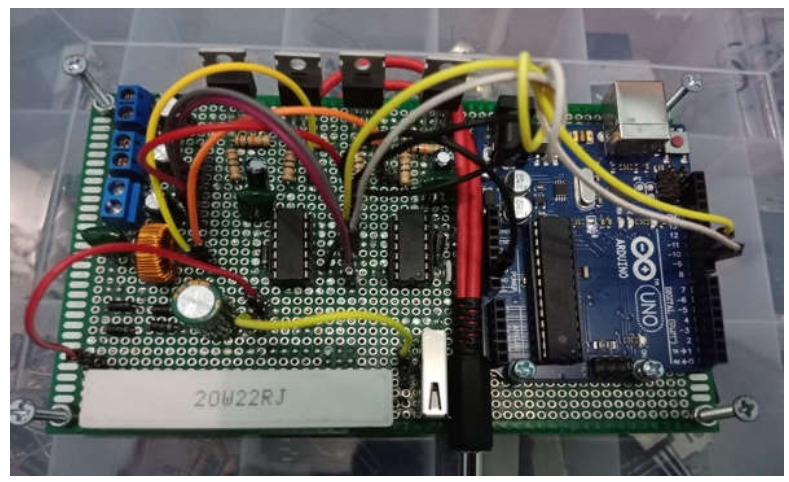

Figure 5. The implemented series resonant DC-DC converter

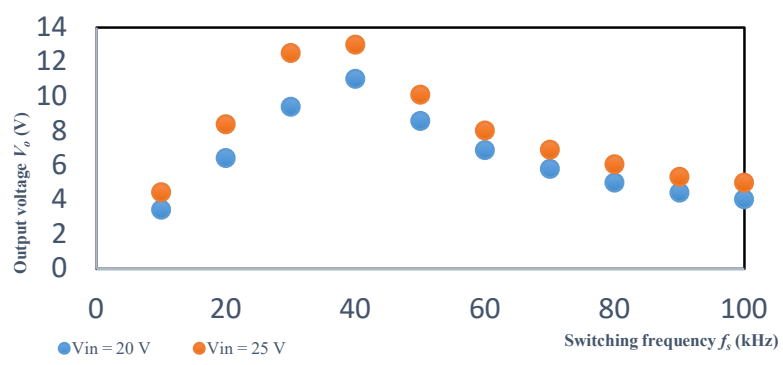

Figure 6. Output voltage vs switching frequency of the developed converter

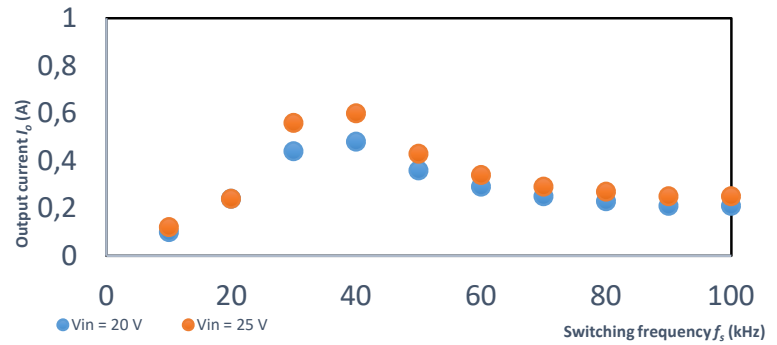

Figure 7. Output current vs switching frequency of the developed converter

As can be seen in Fig. 6 and Fig. 7, the maximum output voltage and current of the developed converter were achieved when switching frequency was at $40 \mathrm{kHz}$ and the minimum output voltage and current were obtained at switching frequency of $10 \mathrm{kHz}$. Maximum recorded voltage values are $10.4 \mathrm{~V}$ and $13.1 \mathrm{~V}$ for input voltage values of $20 \mathrm{~V}$ and $25 \mathrm{~V}$, respectively. The switching frequency of $40 \mathrm{kHz}$ is actually close to the theoretical resonant frequency of around $50 \mathrm{kHz}$. However, this error could be accepted since the output voltage and current at switching frequency of $50 \mathrm{kHz}$ is not that different from those at $40 \mathrm{kHz}$.

The second test was aimed at observing converter voltage efficiency. This test was conducted at optimal frequency, which is $40 \mathrm{kHz}$, as stated before. Similar to the previous one, it was carried out by measuring converter output voltage at different input voltage values. The results for $V_{\text {in }}=20 \mathrm{~V}, V_{\text {in }}=25 \mathrm{~V}$, and $V_{\text {in }}=30 \mathrm{~V}$ are presented in Fig. 8, Fig. 9, and Fig. 10, respectively. As converter is designated to produce half of input voltage, voltage efficiency was judged on how much output voltage differs from it. As can be seen in Fig. 8, Fig. 9, and Fig. 10, the output voltage values are more than $90 \%$ of the values they are supposed to be, i.e. $94.7 \%$ for $V_{\text {in }}=20 \mathrm{~V}, 91.6 \%$ for $V_{i n}=25 \mathrm{~V}$, and $92.2 \%$ for $V_{\text {in }}=30 \mathrm{~V}$.

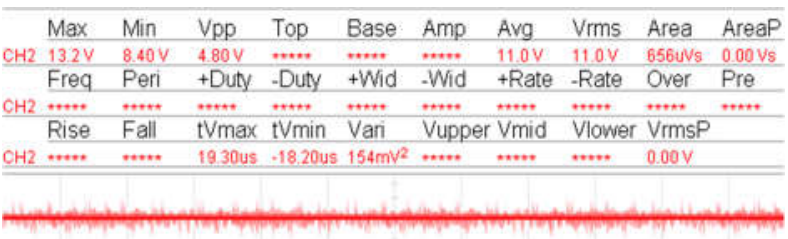

Figure 8. Output voltage of the developed converter when $V_{\text {in }}=20 \mathrm{~V}$ and $f_{s}=40$ $\mathrm{kHz}$ 


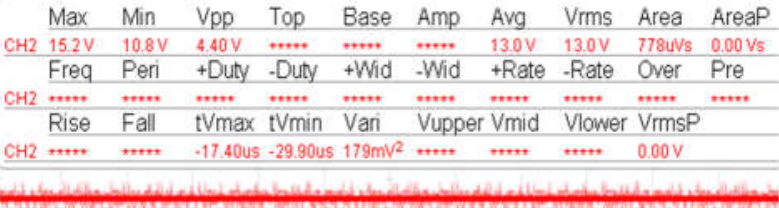

Figure 9. Output voltage of the developed converter when $V_{\text {in }}=25 \mathrm{~V}$ and $f_{s}=40$ $\mathrm{kHz}$

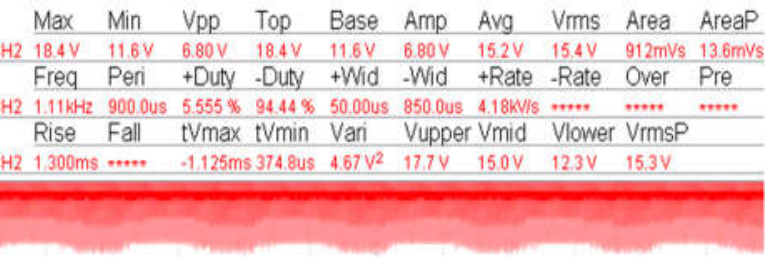

Figure 10. Output voltage of the developed converter when $V_{\text {in }}=30 \mathrm{~V}$ and $f_{s}=$ $40 \mathrm{kHz}$

The third assessment involved observing converter power efficiency. This was done by calculating output power and efficiency using (8). The calculation results for different switching frequencies are presented in Table 2, Table 3 , and Table 4. As can be seen, with input power of approximately $20 \mathrm{~W}$, converter produced half of it, indicating a power efficiency of about $50 \%$.

Table 2. Converter output for $V_{\text {in }}=20 \mathrm{~V}$

\begin{tabular}{|c|c|c|c|}
\hline $\begin{array}{c}\text { Switching } \\
\text { frequency } f_{s}\end{array}$ & $\begin{array}{c}\text { Output } \\
\text { voltage } V_{o}\end{array}$ & $\begin{array}{c}\text { Output } \\
\text { current } I_{o}\end{array}$ & $\begin{array}{c}\text { Output } \\
\text { power } P_{o}\end{array}$ \\
\hline $10 \mathrm{kHz}$ & $3,42 \mathrm{~V}$ & $0,1 \mathrm{~A}$ & $0,342 \mathrm{~W}$ \\
$20 \mathrm{kHz}$ & $6,41 \mathrm{~V}$ & $0,24 \mathrm{~A}$ & $1,54 \mathrm{~W}$ \\
$30 \mathrm{kHz}$ & $9,40 \mathrm{~V}$ & $0,44 \mathrm{~A}$ & $4,14 \mathrm{~W}$ \\
$40 \mathrm{kHz}$ & $10,40 \mathrm{~V}$ & $0,48 \mathrm{~A}$ & $5 \mathrm{~W}$ \\
$50 \mathrm{kHz}$ & $8,56 \mathrm{~V}$ & $0,36 \mathrm{~A}$ & $3,08 \mathrm{~W}$ \\
$60 \mathrm{kHz}$ & $6,88 \mathrm{~V}$ & $0,29 \mathrm{~A}$ & $2 \mathrm{~W}$ \\
$70 \mathrm{kHz}$ & $5,79 \mathrm{~V}$ & $0,25 \mathrm{~A}$ & $1,45 \mathrm{~W}$ \\
$80 \mathrm{kHz}$ & $4,98 \mathrm{~V}$ & $0,23 \mathrm{~A}$ & $1,15 \mathrm{~W}$ \\
$90 \mathrm{kHz}$ & $4,40 \mathrm{~V}$ & $0,21 \mathrm{~A}$ & $0,92 \mathrm{~W}$ \\
$100 \mathrm{kHz}$ & $4,02 \mathrm{~V}$ & $0,21 \mathrm{~A}$ & $0,844 \mathrm{~W}$ \\
\hline
\end{tabular}

Table 3. Converter output for $V_{\text {in }}=25 \mathrm{~V}$

\begin{tabular}{|c|c|c|c|}
\hline $\begin{array}{c}\text { Switching } \\
\text { frequency } f_{s}\end{array}$ & $\begin{array}{c}\text { Output } \\
\text { voltage } V_{o}\end{array}$ & $\begin{array}{c}\text { Output } \\
\text { current } I_{o}\end{array}$ & $\begin{array}{c}\text { Output } \\
\text { power } P_{o}\end{array}$ \\
\hline $10 \mathrm{kHz}$ & $4,43 \mathrm{~V}$ & $0,12 \mathrm{~A}$ & $0,53 \mathrm{~W}$ \\
$20 \mathrm{kHz}$ & $8,38 \mathrm{~V}$ & $0,29 \mathrm{~A}$ & $2,43 \mathrm{~W}$ \\
$30 \mathrm{kHz}$ & $12,50 \mathrm{~V}$ & $0,56 \mathrm{~A}$ & $7 \mathrm{~W}$ \\
$40 \mathrm{kHz}$ & $13,1 \mathrm{~V}$ & $0,43 \mathrm{~A}$ & $5,63 \mathrm{~W}$ \\
$50 \mathrm{kHz}$ & $10,10 \mathrm{~V}$ & $0,34 \mathrm{~A}$ & $3,43 \mathrm{~W}$ \\
$60 \mathrm{kHz}$ & $8,12 \mathrm{~V}$ & $0,29 \mathrm{~A}$ & $2,35 \mathrm{~W}$ \\
$70 \mathrm{kHz}$ & $6,90 \mathrm{~V}$ & $0,29 \mathrm{~A}$ & $2 \mathrm{~W}$ \\
$80 \mathrm{kHz}$ & $6,06 \mathrm{~V}$ & $0,27 \mathrm{~A}$ & $1,64 \mathrm{~W}$ \\
\hline
\end{tabular}

\begin{tabular}{|c|c|c|c|}
\hline $\begin{array}{c}\text { Switching } \\
\text { frequency } f_{s}\end{array}$ & $\begin{array}{c}\text { Output } \\
\text { voltage } V_{o}\end{array}$ & $\begin{array}{c}\text { Output } \\
\text { current } I_{o}\end{array}$ & $\begin{array}{c}\text { Output } \\
\text { power } P_{o}\end{array}$ \\
\hline $90 \mathrm{kHz}$ & $5,34 \mathrm{~V}$ & $0,25 \mathrm{~A}$ & $1,34 \mathrm{~W}$ \\
$100 \mathrm{kHz}$ & $4,98 \mathrm{~V}$ & $0,25 \mathrm{~A}$ & $1,25 \mathrm{~W}$ \\
\hline
\end{tabular}

Table 4. Converter output for $V_{\text {in }}=30 \mathrm{~V}$

\begin{tabular}{|c|c|c|c|}
\hline $\begin{array}{c}\text { Switching } \\
\text { frequency } f_{s}\end{array}$ & $\begin{array}{c}\text { Output } \\
\text { voltage } V_{o}\end{array}$ & $\begin{array}{c}\text { Output } \\
\text { current } I_{o}\end{array}$ & $\begin{array}{c}\text { Output } \\
\text { power } P_{o}\end{array}$ \\
\hline $10 \mathrm{kHz}$ & $8,43 \mathrm{~V}$ & $0,32 \mathrm{~A}$ & $2,70 \mathrm{~W}$ \\
$20 \mathrm{kHz}$ & $10,27 \mathrm{~V}$ & $0,59 \mathrm{~A}$ & $6,06 \mathrm{~W}$ \\
$30 \mathrm{kHz}$ & $13,30 \mathrm{~V}$ & $0,66 \mathrm{~A}$ & $8,78 \mathrm{~W}$ \\
$40 \mathrm{kHz}$ & $15 \mathrm{~V}$ & $0,73 \mathrm{~A}$ & $11 \mathrm{~W}$ \\
$50 \mathrm{kHz}$ & $13,13 \mathrm{~V}$ & $0,61 \mathrm{~A}$ & $8 \mathrm{~W}$ \\
$60 \mathrm{kHz}$ & $12,24 \mathrm{~V}$ & $0,49 \mathrm{~A}$ & $6 \mathrm{~W}$ \\
$70 \mathrm{kHz}$ & $11,35 \mathrm{~V}$ & 0,44 & $5 \mathrm{~W}$ \\
$80 \mathrm{kHz}$ & $10,87 \mathrm{~V}$ & $0,37 \mathrm{~A}$ & $4,02 \mathrm{~W}$ \\
$90 \mathrm{kHz}$ & $9,56 \mathrm{~V}$ & $0,30 \mathrm{~A}$ & $2,87 \mathrm{~W}$ \\
$100 \mathrm{kHz}$ & $9,32 \mathrm{~V}$ & $0,30 \mathrm{~A}$ & $2,8 \mathrm{~W}$ \\
\hline
\end{tabular}

In addition, the developed converter was also tested with practical load of a $12-\mathrm{V}$ electric drill. This test was performed to see converter performance when its load was increased. The output voltage before and after being connected to the electric drill measured by oscilloscope are shown in Fig. 11 and Fig. 12.

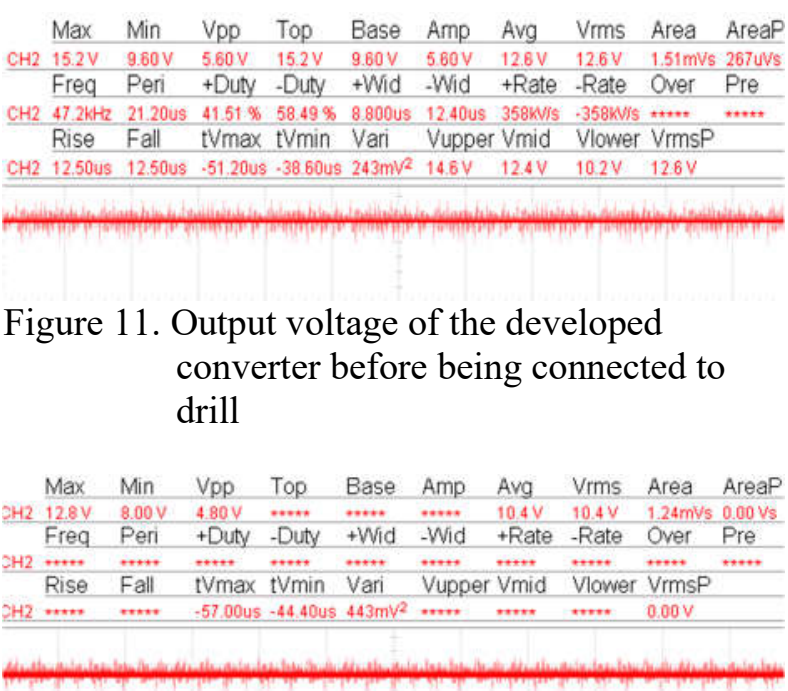

Figure 12. Output voltage of the developed converter after being connected to drill

This electric drill connection experiment showed that there was a decrease in converter output voltage of about $2.2 \mathrm{~V}$. In other words, voltage gain decreased from 0.525 to 0.433 . This gain decrease is actually related to the change of converter quality factor $Q$ due to insertion of electric drill. $Q$ itself is affected by converter 
equivalent resistance $R_{e q}$, as in (7). With the introduction of electric drill, $R_{e q}$ dropped and $Q$ increases, which in turn affected output voltage.

\section{Conclusion}

A small series resonant DC-DC converter has been designed and implemented in this paper. Converter worked by two stages of power conversion, i.e. $\mathrm{DC}$ to $\mathrm{AC}$ conversion and $\mathrm{AC}$ to DC conversion. Output voltage was less than input voltage, resulting in converter work as voltage reducer. In terms of output voltage accuracy, achieved output voltage was very close theoretical value, i.e. around $90 \%$ accuracy. In terms of power efficiency, the developed converter achieved an efficiency of about $50 \%$. When electric drill was connected, the drill worked well but has reduced converter efficiency to a value of about $43 \%$.

\section{References}

[1] D. J. Perreault et al., "Opportunities and challenges in very high frequency power conversion," in 24th Annual IEEE Applied Power Electronics Conference and Exposition - APEC, 2009, pp. 1-14.

[2] D. W. Hart, Power Electronics. New York, NY: McGraw-Hill, 2011.

[3] Y. Nour, A. Knott, and L. P. Petersen, "High frequency soft switching half bridge series-resonant DC-DC converter utilizing gallium nitride FETs," in 19th European Conference on Power Electronics and Applications, 2017, pp. 1-7.

[4] F. A. Pamuji and Soedibyo, "Desain kontrol multi-input DC-DC converter sistem hibrid turbin angin dan sel surya menggunakan kontrol fuzzy logic untuk tegangan rendah," J. Nas. Tek. Elektro, vol. 4, no. 2, pp. 220-226, 2015.

[5] M. Arazi, A. Payman, M. B. Camara, and B. Dakyo, "Study of different topologies of DC-DC resonant converters for renewable energy applications," in 13th International Conference on Ecological Vehicles and Renewable Energies (EVER), 2018, pp. 16.

[6] Y. Lo, C. Lin, M. Hsieh, and C. Lin, "Phase-shifted full-bridge series-resonant DC-DC converters for wide load variations," IEEE Trans. Ind. Electron., vol. 58, no. 6, pp. 2572-2575, 2011.

[7] Y. Shen, H. Wang, Z. Shen, Y. Yang, and F. Blaabjerg, "A 1-MHz series resonant DC-DC Converter with a dual-mode rectifier for PV microinverters," IEEE Trans. Power Electron., vol. 34, no. 7, pp. 6544-6564, 2019.

[8] S. Y. Hui and H. S. H. Chung, "Resonant and Soft-switching Converters," in Power Electronics Handbook: Devices, Circuits, and Applications, 3rd ed., M. H. Rashid, Ed. Burlington, MA: ButterworthHeinemann, 2011, pp. 409-454.

[9] I. Rectifier, "IRFZ44NPbF Datasheet," pp. $1-8,2010$.

[10] A. Vuchev, N. Bankov, A. Lichev, and Y. Madankov, "Load characteristics of a series resonant DC-DC converter with an symmetrical controlled rectifier," in 25 th International Scientific Conference Electronics, 2016.

\section{Author Biography}

Firmansyah Nur Budiman received his M.Sc. in Electrical Engineering from King Saud University, Saudi Arabia. Currently, he is lecturer at Department of Electrical Engineering, Universitas Islam Indonesia, Yogyakarta. His research interest includes design of power converter and power system optimization.

Arridha Amrad received his B.Eng. in Electrical Engineering from Universitas Islam Indonesia, Yogyakarta. He worked on design and implementation of power converter. 